\title{
5 Research Square

\section{Effect of Characterized Pectinase Produced From Aspergillus Niger on the Clarification of Orange and Pineapple Juices}

George D. Ametefe ( $\square$ ametefegeorgee1@gmail.com )

Covenant University

Lemo A. Oluwadamilare

Covenant University

Olubunmi I. Ibidapo

Federal Institute of Industrial Research Oshodi, Lagos State.

\section{Folake Fashola}

Federal Institute of Industrial Research Oshodi, Lagos State.

Frank A. Orji

Federal Institute of Industrial Research Oshodi, Lagos State.

Emeka E. J. Iweala

Covenant University

Shalom N. Chinedu

Covenant University

\section{Research Article}

Keywords: Pectinase, metal ions, temperature, $\mathrm{pH}$, activity, clarification, juice

Posted Date: February 4th, 2021

DOl: https://doi.org/10.21203/rs.3.rs-157765/v1

License: (9) (i) This work is licensed under a Creative Commons Attribution 4.0 International License. Read Full License 


\section{Abstract}

Background: Owing to the importance of enzyme in fruit processing, demand in quality pectinase has increased. As a result, understanding the properties of locally produced pectinase is very important to encourage promotion in its application in the industry. In this study, Aspergillus niger was isolated, screened for its ability to secrete pectinase. The screened Aspergillus niger was used to produce pectinase using solid state fermentation of orange peels.

Results: The effect of temperature and its stability, $\mathrm{pH}$ and its stability, substrate concentration, metal ions $\left(\mathrm{Na}^{+}, \mathrm{Ca}^{2+}, \mathrm{Mg}^{2+}, \mathrm{K}^{+}, \mathrm{Mn}^{2+}, \mathrm{Zn}^{2+}, \mathrm{Co}^{2+}\right.$, and $\left.\mathrm{Fe}^{2}\right)$ were also investigated. The characterized pectinase was applied in the clarification of both orange and pineapple juices. The findings revealed that the enzyme was most effective at $50^{\circ} \mathrm{C}$ and relatively stable at $20^{\circ} \mathrm{C}$ activity of about $0.50 \mathrm{mg} / \mathrm{ml}$ for both. The optimal pH of 5 at about $0.50 \mathrm{mg} / \mathrm{ml}$, and stabilized $\mathrm{pH}$ of 4 with approximately similar activity was also obtained. Of the metals ions investigated, $\mathrm{Na}^{+}$gave the highest activity of about $0.61 \mathrm{mg} / \mathrm{ml}$ compared to ethylenediamine tetraacetic acid (EDTA) which displayed an inhibitory effect. On further optimizing for the concentration of $\mathrm{Na}^{+}$, low concentration of the ion $(10 \mathrm{mM})$ had higher activity of about $0.61 \mathrm{mg} / \mathrm{ml}$. The $\left(\mathrm{K}_{\mathrm{m}}\right)$ and $\mathrm{Vmax}$ was about $0.36 \mathrm{mg} / \mathrm{ml}$ and $4.39 \mathrm{U} / \mathrm{ml}$.

Conclusion: The characterized pectinase clarified both orange and pineapple juices, with enhanced clarification in orange juice compared to pineapple juice. Therefore, the characterized crude pectinase was suitable for application in the clarification of juices.

\section{Background}

The abundance of agrowastes has created suitable breeding ground for pathogens and this is a cause for concern, with negative implications on the environment and health. However, these agrowastes can be used in the production of enzymes [1,2] which are used for various industrial applications. One of such significant enzymes is pectinase which depolymerizes/splits polygalactouronic acid to monomers through glycosidic and esterification cleavages [3-5].

In contrast to plants, microbial pectinases account for $25 \%$ of the global food and industrial enzyme sales [6,7] and their market is increasing day by day [8]. Microbial pectinases are used extensively for fruit juice clarification and extraction [4] wastewater treatment, degumming of vegetables fiber, tea/coffee processing etc. $[9,10]$.

Unlike bacteria, fungi like Aspergillus spp, Penicillium spp and Moniliella SB9 have been studied for production of extracellular pectinase. These fungi are also mostly subjected to solid-state fermentation for the production of extracellular pectinase, because of high secretion and ease of extraction [11-13].

Different factors such as temperature, $\mathrm{pH}$, substrate concentration has been shown by studies to influence the properties of enzymes $[4,8,14]$. In fruit processing, the performance of pectinase significantly affects the outcome or quality of product and processes such as yield and turbidity, thereby, 
leading to enhancement of the clarification process. Since the performance of enzyme is significant for intended application, the characterization of pectinase is vital. Hence, the present study aimed at characterizing the pectinase produced from Aspergillus niger, and determining its suitability for the clarification of orange and pineapple juices.

\section{Methods}

\section{Substrate collection}

The fruits were sourced from the bulk fruit section in the Nigerian Army Shopping Arena, Oshodi, Lagos State; Nigeria. The substrates (orange peels) were derived from the peeling of the oranges sourced. The substrates were then washed and dried in an oven for 48 hours at $58^{\circ} \mathrm{C}$ before milling into a particle size of 0.06 inch in a Hammer mill to allow for an increase in surface area for effective microbial action.

\section{Isolation and screening of pectinase producing Aspergillus spp.}

Deteriorated fruits were sourced from dumpsites and soils in the Federal Institute of Industrial Research, Oshodi (FIIRO), Lagos State, Nigeria. Serial dilution was carried out. Each dilution was subjected to pourplating technique using streptomycin as the antibiotic, and incubated for 5 days at $25^{\circ} \mathrm{C}$. The isolate was selected and sub cultured to purity. The purified isolate was microscopically identified [15] and molecularly identified using the method [16,17].

The preliminary screening of the isolated microbe for pectinase production was done using the Czapek medium $[16,18]$.

\section{Production and extraction of pectinase}

Solid-state fermentation of orange peel was carried out: 2 grams were weighed into each labeled flask and moistened with $2 \mathrm{ml}$ of a nutrient medium composed of: $(\mathrm{g} / \mathrm{l}) 0.6 \mathrm{KCl}, 0.60 \mathrm{KH}_{2} \mathrm{PO}_{4}, 0.60 \mathrm{KNO}_{3}, 0.60$ $\mathrm{K}_{2} \mathrm{HPO}_{4}$, and $0.10 \mathrm{MgSO}_{4}$ at $\mathrm{pH}$ of 4 . This mixture was autoclaved at $121^{\circ} \mathrm{C}$ for 15 minutes. After that, the flasks were cooled to room temperature. One percent of citrus pectin as an inducer was aseptically added to the contents. The mixture was inoculated with the identified Aspergillus niger and incubated at $30^{\circ} \mathrm{C}$ for six days $[4,19]$. Extraction of the enzyme was done using $0.1 \mathrm{M} \mathrm{NaCl}$ solution [4].

\section{Assay for pectinase activity}

The procedure by Miller [20] was employed with modifications: $3 \mathrm{ml}$ of $1 \%$ pectin solution was measured into $1 \mathrm{ml}$ of the crude pectin enzyme. The mixture was incubated at $50^{\circ} \mathrm{C}$ in a water bath for 10 minutes. After which, $1 \mathrm{ml}$ of freshly prepared Dinitrosalicylic acid (DNSA) solution was added and boiled for 5 minutes. This was left to cool to room temperature. The absorbance was taken using UV-Vis spectrophotometer which was preset at $540 \mathrm{~nm}$ and galacturonic acid was used as standard. 
The effect of temperature and its stability, $\mathrm{pH}$ and its stability and metal ions $\left(\mathrm{Na}^{+}, \mathrm{Ca}^{2+}, \mathrm{Mg}^{2+}, \mathrm{K}^{+}, \mathrm{Mn}^{2+}\right.$, $\mathrm{Zn}^{2+}, \mathrm{Co}^{2+}$, and $\mathrm{Fe}^{2+}$ ) were also investigated prior to application in orange and pineapple juices by the method described [21] with modifications. Concentrations $(10,20,30,40$, and $50 \mathrm{mM})$ varied for the best metal ion determination.

Substrate concentrations was determined and the Lineweaver Burk plot was used to calculate the $\mathrm{V}_{\max }$ and $\mathrm{K}_{\mathrm{m}}$.

\section{Application in clarification of the juice}

The procedure of Roy and colleagues [22], with modification was employed for the pineapple and orange juice clarifications: $2.5 \mathrm{ml}$ of the each of the juices were evenly dispensed into $(0.5,1.0,1.5,2.0$, and $2.5 \mathrm{ml}$ ) labeled test tubes and corresponding volumes of the crude pectinase were added using juice with no crude enzyme as control. The mixtures were swirled to mix, incubated at $50^{\circ} \mathrm{C}$ for one hour as described in Barman [23].

Spectrophotometry method was used for determining the effect of the enzyme on the clarification process: Samples incubation was increased from $50^{\circ} \mathrm{C}$ to $90^{\circ} \mathrm{C}$ for 7 minutes before allowing to cool and reading in the UV-Vis spectrophotometer at $660 \mathrm{~nm}$. Statistical analysis was conducted by plotting the bar charts, analysis of variance (ANOVA), and t-test (for comparison) were undertaken using Microsoft Excel version 2016.

\section{RESULTS AND DISCUSSION}

This study was investigated to determine the effect of temperature, $\mathrm{pH}$, substrate concentrations, metal ion effect on pectinase activity, as well as the effect of the characterized enzyme on clarification of fruit juices.

The increase in activity of pectinase from 20 to $50^{\circ} \mathrm{C}$ and decline in the activity afterwards (Fig. 1) is indicative of the enzyme working best at $50^{\circ} \mathrm{C}$. The reduction in activity beyond $50^{\circ} \mathrm{C}$ could be indication of denaturation of the enzyme. With regards to Fig. 2, the continuous reduction in activity was indicative of the loss in activity during storage at higher temperatures, thereby also resulting the enzyme's denaturation [24].

The enzyme for application purpose is shown to function best at pH of 5 (Fig. 3), while the stability of the enzyme is best achieved at pH of 4 (Fig. 4). The decline in activity after the optimum pH in Figures 3 and 4 , could be due to denaturation of the protein. The optimum $\mathrm{pH}$ so obtained is an indication of the enzyme being acidic; and, further showing its suitability for application in acidic condition.

The effect of the metal ions as investigated varied as shown (Fig 5). A higher activity was observed with $\mathrm{Na}^{+}$and $\mathrm{Mg}^{2+}$ ions with an increase of about 3.08 and $2.22 \%$, compared to EDTA. The increased effect of $\mathrm{Na}^{+}$and $\mathrm{Mg}^{2+}$ ions on the enzyme activity to function well (preferable cofactors), is indicative of these 
ions forming an essential part of the enzyme complex [25]. From values obtained for other metal ions, the negative values obtained (decrease in activity relative control) indicate the inhibitory action of each of the metal ions with highest rate of enzyme inhibition attributed to EDTA. It is possible that EDTA, functioned as a chelating agent $[26,27]$ which drastically reduced the efficacy of the enzyme to effectively function. The effect of various concentrations of the $\mathrm{Na}^{+}$ions as shown in Figure 6, led to reduction in activity of the enzyme with increase in concentration. This suggests higher concentration beyond $10 \mathrm{mM}$ probably occupied the active sites on the enzyme, and further reducing the interaction of such active sites with the substrates, leading to loss in activity of the enzyme on the available substrates.

As $\mathrm{Km}$ is the substrate concentration at which the enzyme is active, therefore, the pectin enzyme produced was active at $0.3620 \mathrm{mg} / \mathrm{ml}$ of substrate concentration [14]. The equation of the LineweaverBurk plot was obtained as $y=0.0824 x+0.2276$ with $R^{2}$ of 0.9685 . The $V$ max was found to be 4.39 $\mathrm{U} / \mathrm{ml}$.

The effect for the action of the enzyme in the clarification of the orange juice was shown to be significant in the splitting the pectin for $30 \%$ and $40 \%$ (Fig. 7). More of the enzyme was required for the clarification action of the juice to be obtained. It is worthy to note that, $40 \%$ pectinase in relation to the amount of juice led to higher activity. However, the clarification of the enzyme on pineapple juice (as shown in Figure 8) did not result in similar significant reduction in pectinase activity. It was however shown to have similar effect on the clarification of the juices. The higher effect on orange juice clarification (Fig.7) in comparison to pineapple juice (Fig. 8) could result from the substrate used in the production of the enzyme.

\section{Conclusion}

Crude pectin enzyme produced from locally sourced Aspergillus niger has been characterized and applied in the clarification of orange and pineapple juices. The characterized crude pectinase was found to clarify both orange and pineapple juices.

\section{Declarations}

\section{Ethics approval and consent to participate}

Not applicable

\section{Consent for publication}

Not applicable

\section{Availability of data and materials}

The datasets used during the study can be made available from the corresponding author on reasonable request. 


\section{Conflict of interest}

The authors declare no conflict of interest.

\section{Funding}

The study was self-funded with no funding received from any funding agency.

\section{Authors' contribution}

George D. Ametefe conceived the idea and executed it, Lemo A. Oluwadamilare was involved in sourcing of the substrates and preparation for fermentation. The taking of the absorbance readings for the assay was read by Olubunmi I. Ibironke, while Folake Fashola interpreted the readings obtained from the spectrophotometer. The laboratory (on-site) supervisor was Frank A. Orji, with Emeka E.J. Iweala and Shalom N. Chinedu were involved from the conception of the idea to the finishing stages of the study, as they were the corresponding author's Ph.D. co and main supervisors respectively.

\section{Acknowledgment}

The authors are thankful to Covenant University, Ota; Ogun State, Nigeria and the Enzyme division of the Federal Institute of Industrial Research, Oshodi (FIIRO) Lagos State, Nigeria; for the use of their facilities.

This research did not receive any grant from funding agencies in the public, commercial, or not-for-profit sectors.

\section{Significance statement}

This study showed the characterization of pectinase for clarification of fruit juices (orange and pineapple juices). This shows the importance of different factors that influence pectin enzyme activity. This includes temperature, $\mathrm{pH}$, substrate concentration and metal ion. It also indicates the importance of determining and understanding the preferable conditions for maximizing pectin enzyme potential prior to its application.

\section{References}

1. Obi F. O., Ugwuishiwu B. O., Nwakaire, J. N. Agricultural waste concept, generation, utilisation and management. Nigerian Journal of Technology (NIJOTECH), 2016, 35(4): 957-964.

2. Sadh P. K., Duhan S., Duhan J. S. Agro-industrial wastes and their utilisation using solid state fermentation: a review. Bioresources and Bioprocessing, 2018, 5: 1.

3. Adelakun G.I., Adigun A.I., Niyi A.S.B., Tayo O.J.O. 2019. An assessment of the effectiveness of the waste bins collection and disposal in Sango-Ota, Ogun State, Nigeria. World Science News, 2019, $119,27-40$. 
4. Ametefe G.D., Dzogbefia V.P., Apprey C., Kwatia S. Optimal conditions for pectinase production by Saccharomyces cerevisiae (ATCC 52712) in solid state fermentation and its efficacy in orange juice extraction. IOSR. J. of Biotechnology and Biochemistry, 2017, 3(6), 78-86.

5. Saranraj P., Naidu, M.A. Microbial pectinases: a review. Global Journal of Traditional Medical Systems, 2014, 3(1), 1-9.

6. Jayani R. S., Saxena S., Gupta R. Microbial pectinolytic enzymes: a review. Process Biochemistry, 2005, 40 (9): 2931-2944.

7. Jayani R. S., Shukla S. K., Gupta R. Screening of bacterial strains for polygalacturonase activity: its production by Bacillus sphaericus (MTCC 7542). Enzyme Research, Article ID 306785, 5 pages, 2010.

8. Oliyad J. O., Dawit A. Characterization of Pectinase from Bacillus subtilis strain Btk 27 and its potential application in removal of mucilage from coffee beans. Enzyme Research, Article ID 7686904, 7 pages, 2017. https://doi.org/10.1155/2017/7686904.

9. Semenova M., Sinitsyna O., Morozova V. Use of preparation from fungal pectin lyase in the food industry. Applied Biochemistry and Microbiology, 2006, 42, 598-602.

10. Tucker G. A., Woods, L. F. J. Enzymes in production of Beverages and Fruit juices. Enzymes in food processing, Blackie, New York, 1991, Pp. 201-203.

11. Sudeep K. C., Upadhyaya J., Joshi D. R., Lekhak B., Chaudhary D., Pant B. R.... \& Raghavan V. (2020). Production, characterisation and industrial application of pectinase enzyme isolated from fungal strains. Fermentation, 2020, 6, 59-69.

12. El Enshasy H., ELsayed E.A., Suhaimi, N., Malek, R.A., Esawy, M. Bioprocess optimization for pectinase production using Aspergillus niger in a submerged cultivation system. BMC Biotechnology, 2018, 18: 71. https://doi.org/10.1186/s12896-018-0481-7.

13. Martin N., Souza, S.M., da Silva R., Gomes, E. Pectinase production by fungal strains in solid-state fermentation using agro-industrial bioproduct. Brazilian Archives of Biology and Technology, 2004, 47(5): 813-819.

14. Chinedu S. N., Dayo-Odukoya O. P., Iheagwam F. N. Partial purification and kinetic properties of polygalacturonase from Solanum macrocarpum L. fruit. Biotechnology, 017, 16(1): 27-33.

15. Udenwobele D. I., Nsude C. A., Ezugwu A. L., Eze S. O., Anyawu C., Uzoegwu P. N., Chilaka F. C. Extraction, partial purification and characterisation of pectinases isolated from Aspergillus species cultured on mango (Mangifera indica) peels. African Journal of Biotechnology, 2014, 13(24), 2245-2454.

16. Khattab S.M.R., Abdel-Hadi A.M., Abo-Dahab N.F., Atta O.M. Isolation, characterisation, and identification of yeasts associated with foods from Assiut city, British Microbiology Research Journal, 2016, 13(1): 1-10.

17. Wartu J.R., Whong C.M.Z., Abdullahi I.O., Ameh J.B. Phylogenetics of aflatoxogenic moulds and prevalence of aflatoxin from in-process wheat and flour from selected major stores within northern Nigeria. Science World Journal, 2017, 12 (4): 83-87. 
18. Chinedu S. N., Eni A. O., Adeniyi A. O., Ayangbemi, A. (2010). Assessment of growth and cellulase production of wild-type micro fungi isolated from Ota, Nigeria. Asian Journal of Plant Sciences, 2010, 9: 118-125.

19. Reginatto C., Rossi C., Miglioranza B. G., dos-Santos M., Menghel L., da-Silveira M. M., Malvessi, E. (2017). Pectinase production by Aspergillus niger LB-02-SF is influenced by the culture medium composition and the addition of the enzyme inducer after biomass growth. Process Biochemistry, 2017, 58: 1-8.

20. Miller G. L. (1959). Modified DNS method for reducing sugars. Analytical Chemistry, 1959, 31(3): 426428.

21. Ahmed, A. \& Sohail, M. Characterisation of pectinase from Geotrichum candidum AA15 and its potential application in orange juice clarification. Journal of King Saud University-Science, 2019, 32, 955-961.

22. Roy K., Dey S., Uddin K., Barua R., Hossain T. Extracellular pectinase from a novel bacterium Chryseobacterium indologenes strain SD and its application in fruit juice clarification. Enzyme Research, Article ID 3859752, 2018. doi:10.1155/2018/3859752.

23. Barman S., Sit N., Badwaik L. S., Deka S. C. Pectinase production by Aspergillus niger using banana (Musa balbisiana) peel as substrate and its effect on clarification of banana juice. Journal of Food Science and Technology, 2015, 52(6): 3579-3589.

24. Vitolo M. Brief review on enzyme activity. World Journal of Pharmaceutical Research, 2020, 9(2), 6076.

25. Torimiro N., Adediwura V. A., Ojo S. T., Oluwadare A. O., Okonji R. E. (2018). Pectinolytic activities of pectinase produced by some bacterial isolates cultured from deteriorating fruits. Nigerian Journal of Biotechnology, 2018, 35(2): 91-98.

26. Anand G., Yadav S., Yadav D. Production, purification and biological characterisation of an exopolygalacturonase from Aspergillus niger MTCC 478 suitable for clarification of orange juice. 3 Biotechnology, 2017, 7, 1-8.

27. Okonji, R. E., Itakorode, B. O., Ovumedia, J. O. \& Adedeji, O. S. (2019). Purification and biochemical characterisation of pectinase produced by Aspergillus fumigatus isolated from soil of decomposing plant materials. Journal of Applied Biology \& Biotechnology, 7(3), 1-8.

\section{Figures}




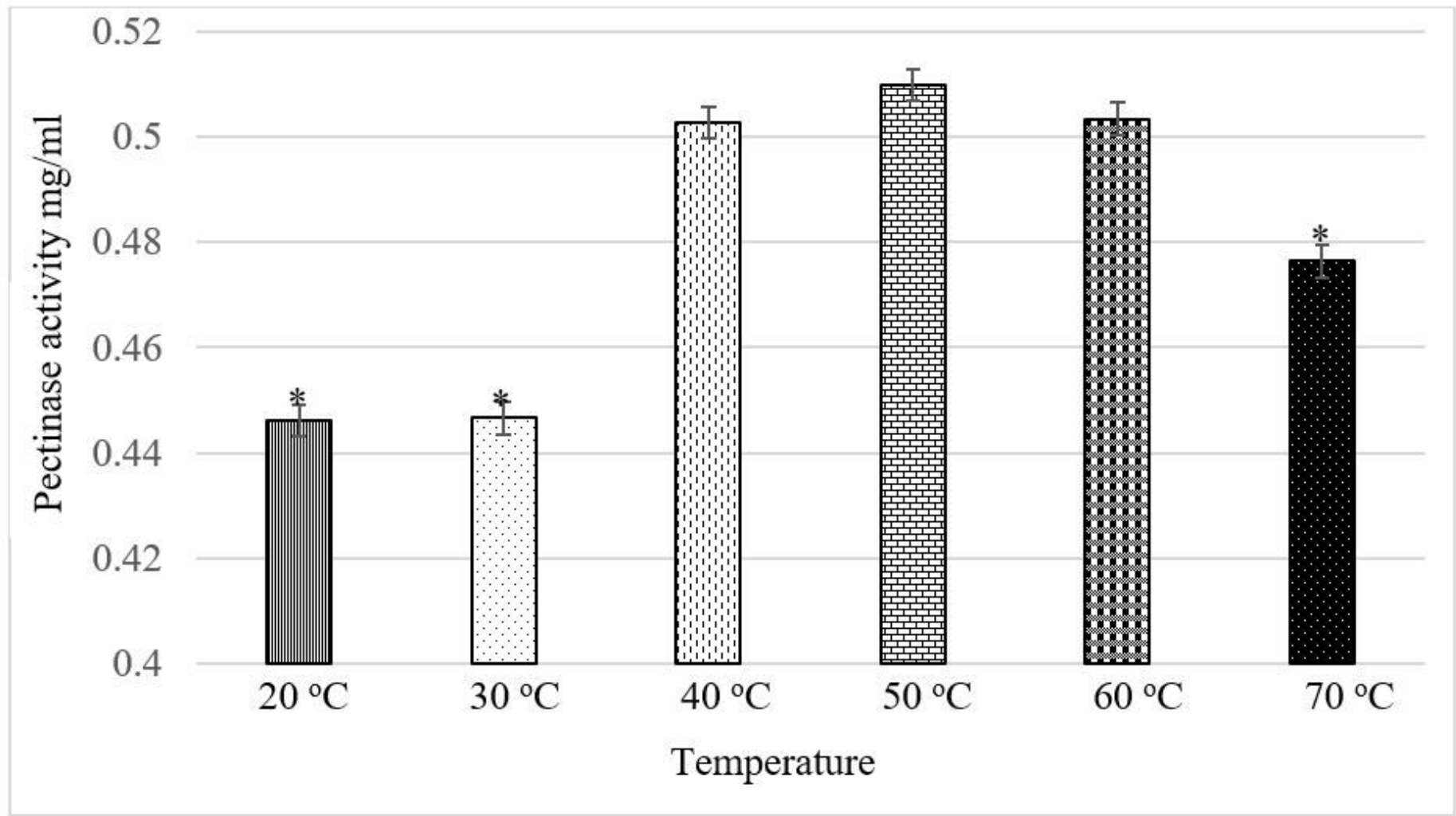

Figure 1

Effect of temperature on the pectinase activity Where * denotes significant difference with 50 oC

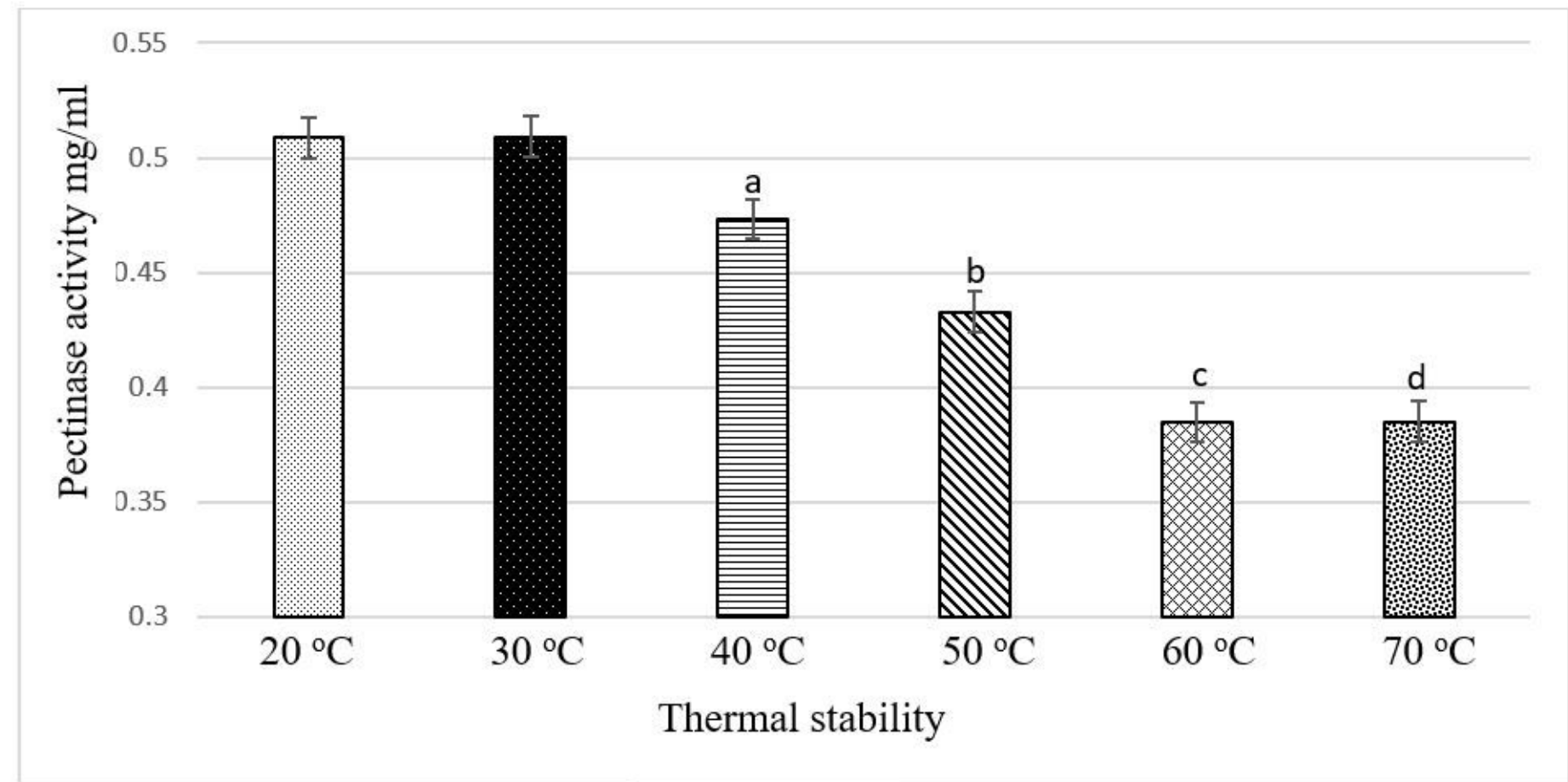

Figure 2 


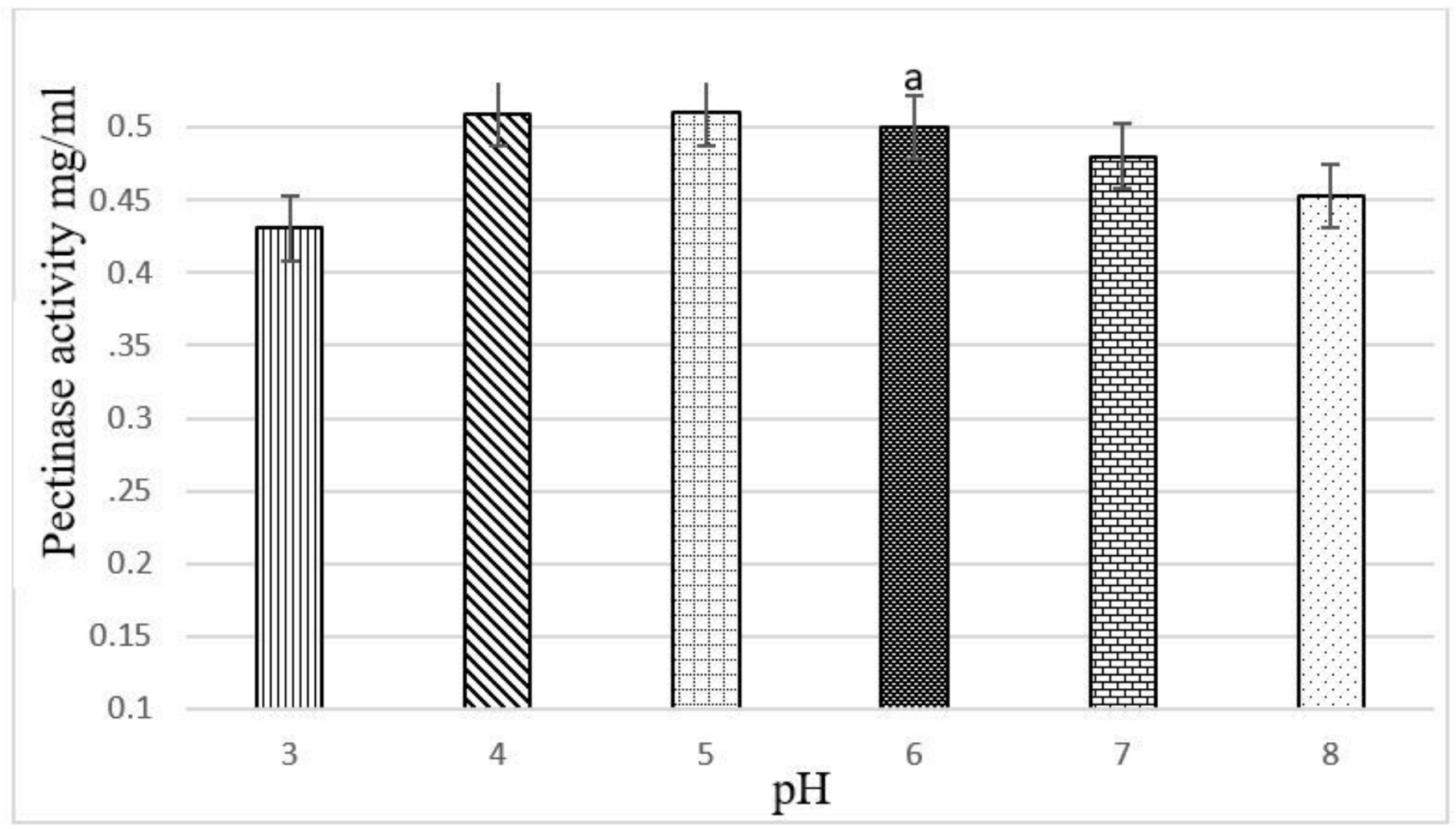

Figure 3

$\mathrm{pH}$ effect on the enzyme's activity (pH 5 as control) 


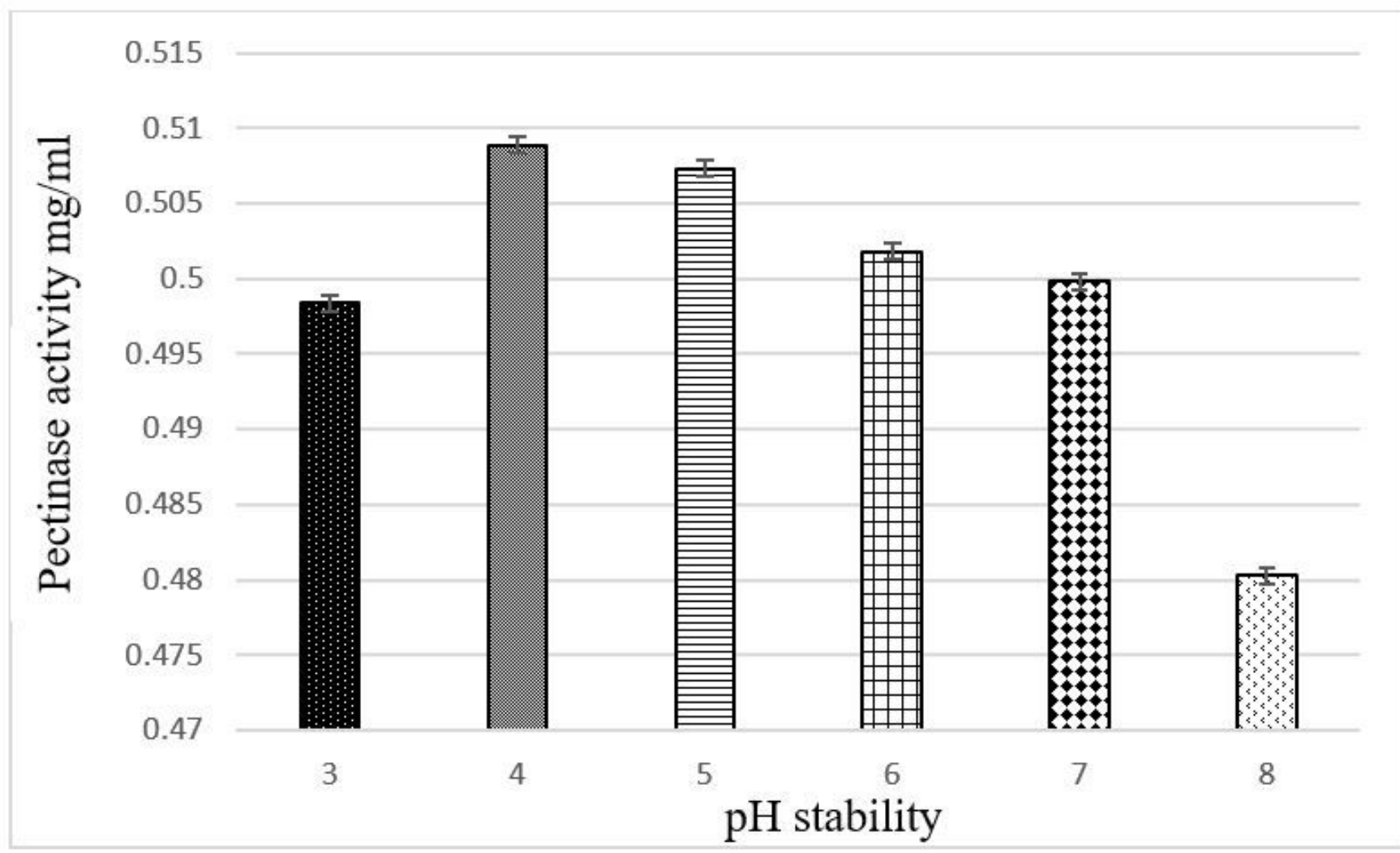

Figure 4

Effect of pH stability on enzyme's activity 


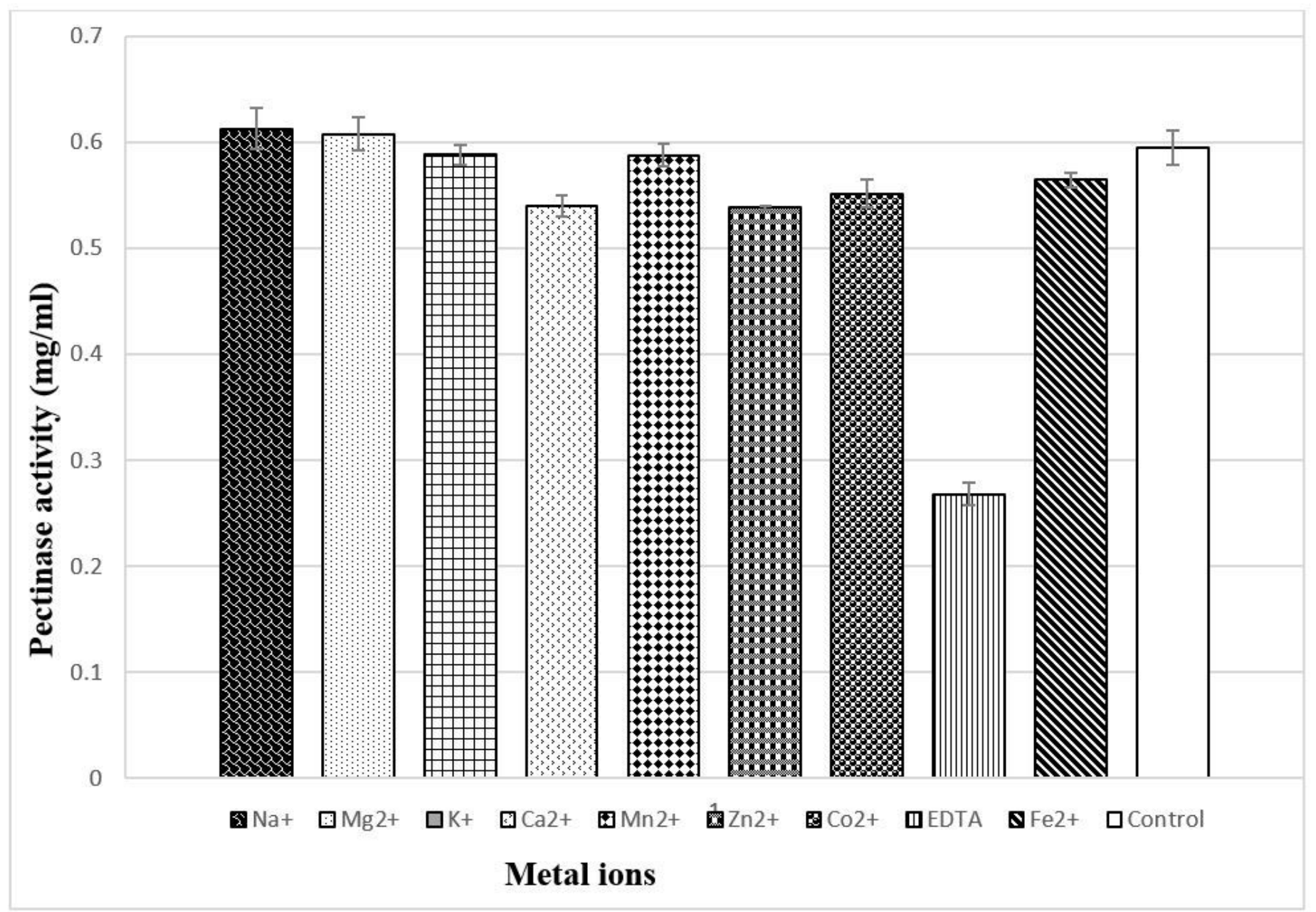

Figure 5

Different metal ions and their effect on the pectinase activity 


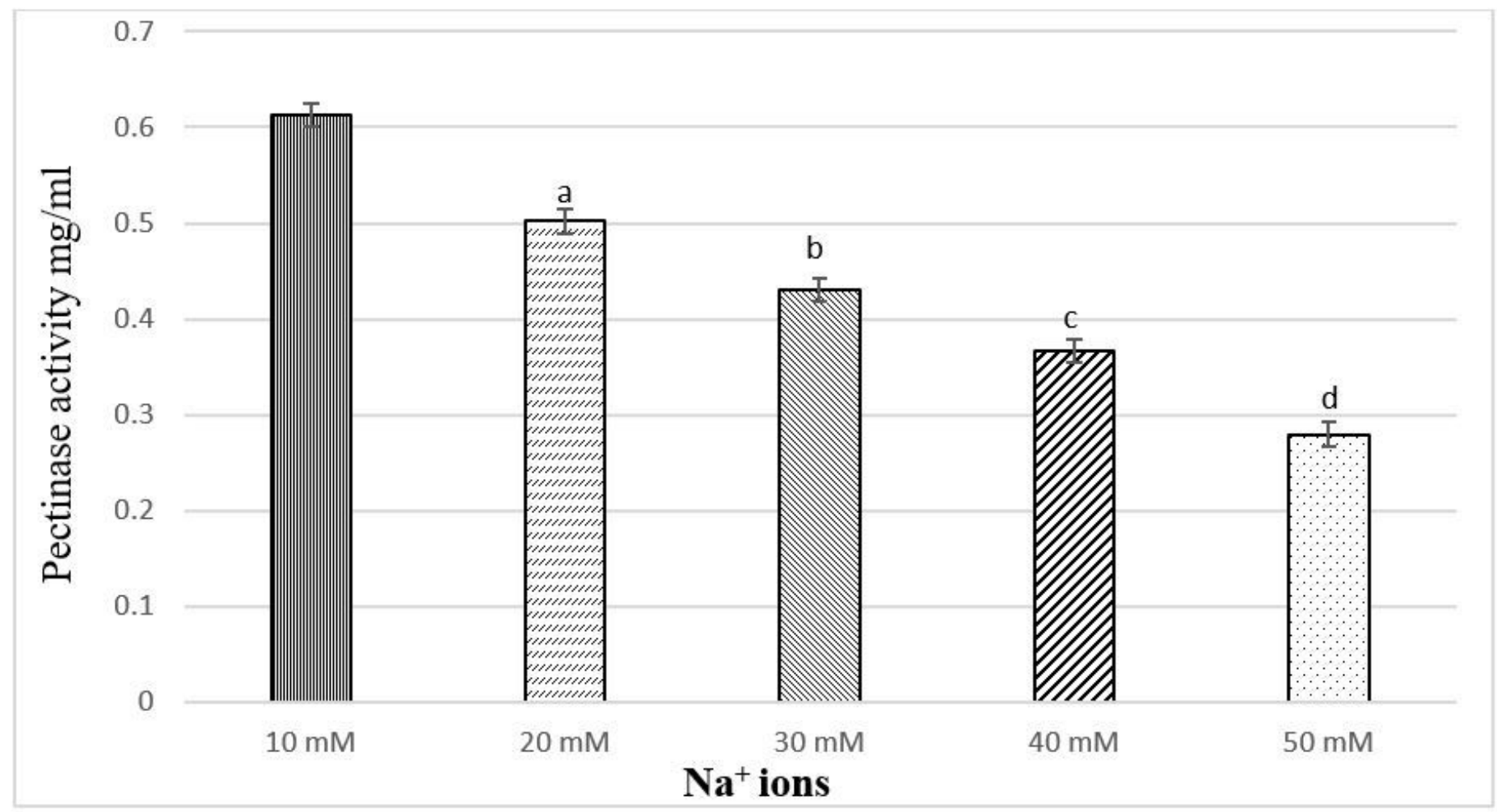

Figure 6

Effect of various concentration of $\mathrm{Na}+$ ions on pectinase activity 


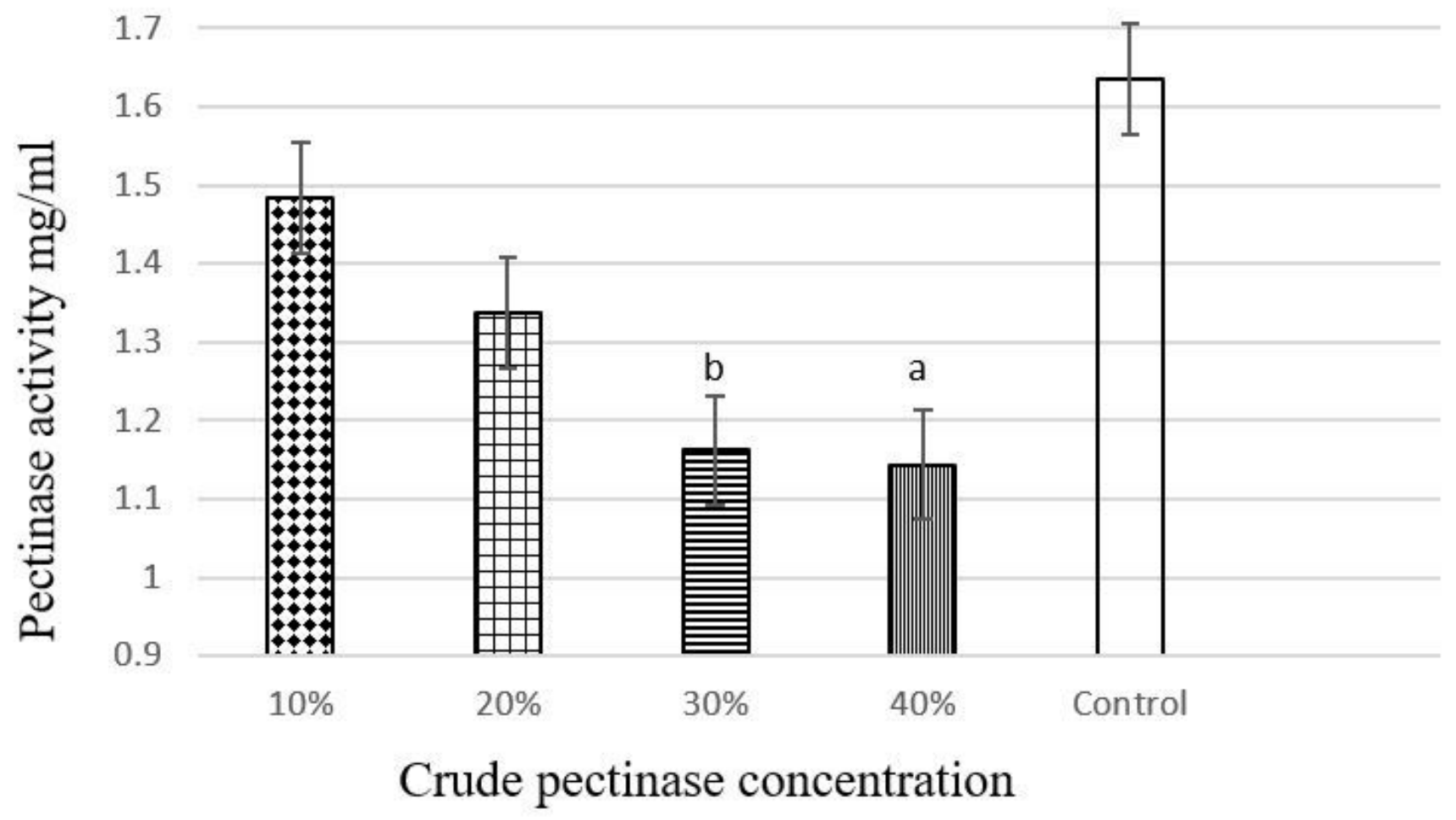

Figure 7

The crude pectinase effect on the clarification of orange juice Where ' $a$ ' and ' $b$ ' indicates a significant decrease in activity relative to the control 


\subsection{5}

\subsection{3}

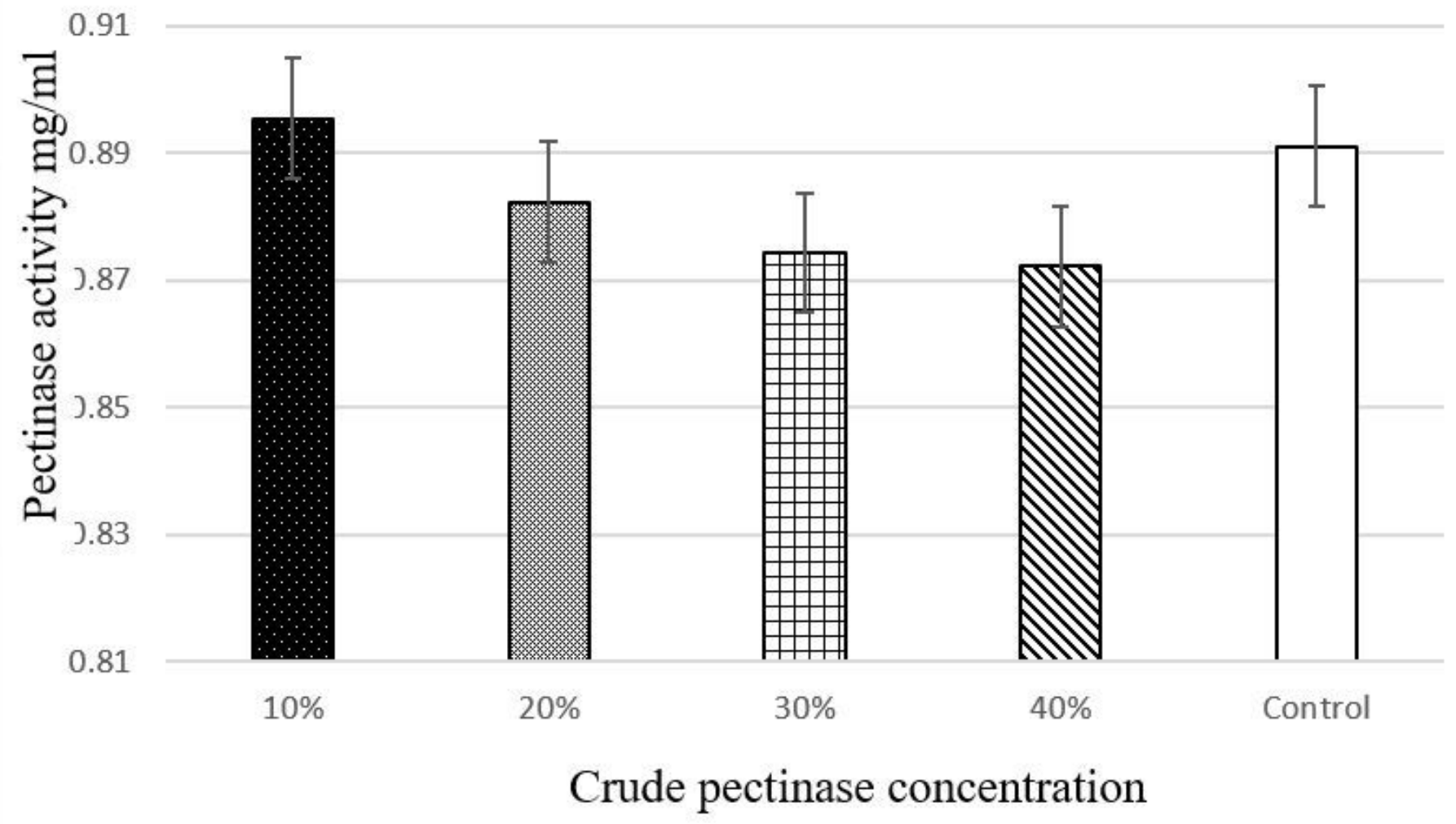

Figure 8

The crude pectinase effect on the clarification of pineapple juice 